\title{
Pochówki i pamięć poległych (XIV-XVII w.)
}

Marek Janicki 
nAP7S Seria VII 2001

\title{
Marek Janicki
}

\section{Pochówki i pamięć poległych (XIV-XVII w.)}

\begin{abstract}
Tradycja oddawania czci poległym szczególną rangę zyskała w kulturze greckiej. Według Tukidydesa:
\end{abstract}

Kości [bohaterów - M. J.] składa się do grobowca wystawionego przez państwo na najpiękniejszym przedmieściu ateńskim, gdzie stale chowa się poległych na wojnie; wyjątek stanowili polegli pod Maratonem, gdyż dzielność ich uznano za szczególną i pogrzebano na polu bitwy (II 34) ${ }^{1}$.

Zasadniczym momentem ateńskich uroczystości było wygłoszenie przez wybranego obywatela mowy ku czci poległych — epitafios logos ${ }^{2}$. Społeczne znaczenie pamięci poległych w kulturze greckiej następująco objaśniał Demostenes w mowie ku czci bohaterów spod Cheronei (338 r. p.n.e.):

Dzisiaj uczczeni przez nas wedle naszych zwyczajów dostępują najwyższego publicznego szacunku i wyzwalają przez to wśród innych szlachetne pragnienie współzawodnictwa. Cała Ojczyzna uczestniczy teraz w pogrzebie tych, którym jako jedynym z obywateli przysługują publiczne pochwały $(33)^{3}$.

Miały one być zapłatą za ofiarę życia złożoną w obronie Ojczyzny, a ich społeczny, parenetyczny cel to pobudzenie do naśladownictwa, czy wręcz - jak określił to mówca — współzawodnictwa $z$ poległymi ${ }^{4}$.

1 Tukidydes, Wojna peloponeska, tł. K. Kumaniccki, opr. R. Turasiewicz, Wrocław 1991 (BN II 225), s. 135.

2 Tradycję przemawiania nad grobem poległych wprowadzić miano po bitwie pod Platcjami (479 r. p.n.c.), zob. R. Turasicwicz, Wstęp, w: Tukidydes, op. cit., s. LXXV-LXXVI.

${ }^{3}$ Demostenes, Mowa pogrzebowa, w: idem, WYbór mów, tł. i opr. R. Turasiewicz, Wroclaw 1991 (BN II 15), s. 182; wzorem mowy (ibidem, s.168-183) mógł być cpitaf wygloszony przez Peryklesa (zob. Tukidydes, II 45, op. cit., s. 144). Objaśnienie zwyczaju ateńskiego zob. Demostenes, Mowa..., 1-2; ed. cit., s. 169-170 (por. Tukidydes, II 35, ed. cit., s. 135-136); Platon, Meneksenos, tt. i opr. K. Tuszyńska-Maciejewska, Wrocław 1994, (249 b-c), s. 16.

${ }^{4}$ Zob. Demostenes, loc. cit.; por. Platon (247 c, ed. cit., s. 14-15) - prozopopeja poległych: „... starajcic siç pod 
Jakkolwiek w kulturze staropolskiej nigdy nie wykształciła się - wzorowana na antycznej — tradycja oficjalnych pogrzebów poległych i wygłaszania na ich cześć epitafionów, to jednak kulturowy cel oddawania im czci i utrwalania pamięci o nich, zarówno w miejscach pochówku, jak i zwłaszcza w utworach poetyckich, był w istocie tożsamy: pareneza oraz przekazanie wzorca postępowania w imię trzech naczelnych wartości: honoru, miłości Ojczyzny i wiary.

Jednym z najwcześniejszych świadectw krystalizowania się polskiej świadomości narodowej jest z pewnością zapis o śmierci kasztelana krakowskiego Prędoty (Rawity), poległego zapewne 15-16 kwietnia 1317 roku, podczas odwetowej wyprawy Wladysława Łokietka na Brandenburgię rozpoczętej w roku $1316^{5}$. Autor zapisu, najprawdopodobniej syn kasztelana, także Prędota ${ }^{6}$, w Kalendarzu katedry krakowskiej zanotowal, że kasztelan zakończył życie „w walce za naród polski aż do śmierci"7.

Jan Ostroróg w Monumentum... pro Rei Publicae ordinatione... pisał w wyraźnie napominającym tonie:

Obowiązkiem zaś szlachty jest zawsze być gotowym do obrony Ojczyzny, a także gdy będzie potrzeba umrzeć za Ojczyznę 8 .

Jednakże jeszcze długo potem, aż po XVII stulecie, we wspomnieniach o poległych — jako główny ich tytuł do chwały i pośmiertnej nagrody — akcentowana będzie walka w obronie wiary. Tak też stało się w przypadku literackiego upamiętnienia najsławniejszego polskiego rycerza wszech czasów - Zawiszy Czarnego z Garbowa, przy czym jednak zasadniczą uwagę poświęcono dwu głównym wartościom etosu rycerskiego: honorowi i wierności, ściślej zaś wierności wobec towarzyszy walki ${ }^{9}$.

każdym względem być gotowi do przcścignięcia nas i przodków piękną sławą. Jcśli zaś nic, to wicdzcic, żc gdybyśmy przewyższyli was cnota, to ta przewaga przynosi nam wstyd, a nasze niepowodzcnic szczęścic. Szczcgólnic wówczas zostalibyśmy zwyciężeni, a wy zwycięzcami, gdybyście starali się w swoim postępowaniu nic korzystać ze sławy przodków, a tym bardziej jej nic roztrwonić, wiedząc, że dla człowicka znająccgo swoją wartość nic ma nic bardzicj przykrego, niż przekonać się, że jest siç szanowanym nie ze względu na własne zasługi, alc na sławç swoich przodków".

5 Zob. Prędota (Prandota) z Michowa h. Rawa, w: Polski stownik biograficzny, t. 28, Wrocław 1984-1985, s. 453. Jak stwierdza autor biogramu, Janusz Bicniak: „Obituarną zapiskę o Prędocic w Kalendarzu katedry krakouskiej wykorzystuje nauka jako jeden z przykładów rozwiniçtcj świadomości narodowcj w Polsce XIV w.” (ibidem). Por. M. Błaziak, Uwagi o rycerstuie w „Roczniku Świętokrzyskim Now'ym”, w: Spoleczeństwo Polski średniowiecznej. Zbiór studiów, red. S. K. Kuczyński, Warszawa 1996, s. 201-210 (s. 203).

6 Prepozyt skalbimierski i kanonik krakowski (zm. 1354), por. Kalendarz Katedry Krakowskiej, w: Monumenta Poloniue Historica. Series nova (dalej: MPH s.n.), t. 5: Najdawniejsze roczniki krakowskie i kalendarz, wyd. Z. Kozłowska-Budkowa, Warszawa 1978, s. 126-127.

7 „Prandota filius Warsy castellanus Cracoviensis obiit anno Domini MoCoCoCoXVIIIo pugnando pro gente Polonica usque ad mortem" (MPH s.n., t. 5, s. 140; w zapisic data śmicrci przesuniçta omyłkowo o rok).

8 "Officium autem nobilitatis est semper paratum esse Patriam tueri, etiam, si opus fuerit, mori pro Patria" - Monumentum pro comitiis generalibus Regni sub Rege Casimito pro Reipublicae ordinatione congestum... opera Michaelis Bobrzyński editum, Cracoviae 1877, w: Starodawne prawa polskiego pomniki, t. 5, cz.1, Cracoviae 1878, s. 132, rozdz. 42.

${ }^{9}$ Warto tu przypomnieć, że opozycję zaszczytnej śmierci na polu bitwy i hańbiącej z nicgo ucieczki rozważał w swoim komentarzu do Etyki nikomachejskiej z 1424 r. Pawcł z Worczyna, który w kwcstii „Czy czlowick mçżny powinien raczej wybrać śmierć niż życie, gdyby mógł się ratować ucieczką" pisał: „Jedni przyjmują życic po tym życiu, inni nie. Otóż jeśli się trzymać pierwszego poglądu, jasne jest, że człowick nic traci wszystkich dóbr po śmicrci, owszem, posiądzic byt lepszy niż przed śmiercią, lecz trzymając siç drugiego poglądu powiada się: choć przcz śmicrć traci wszystkie dobra ciała i duszy, to przecicż na krótko posiadł byt najlepszy, mianowicic ostateczny akt męstwa, a byt ten był lepszy niż długie panowanie [lub: długic znoszcnic cudzcgo panowania] w hanicbnym bycic" 
Zawisza zginął w 1428 roku pod Gołubcem nad Dunajem (około $100 \mathrm{~km}$ na wschód od Belgradu), walcząc z Turkami w wojsku Zygmunta Luksemburskiego. Choć ten ofiarował rycerzowi możność ocalenia życia, to - jak zanotował Długosz:

Zawisza jednak jako nader gorliwy strażnik honoru rycerskiego, uważając opuszczenie swych towarzyszy, których już zobaczył w szponach śmierci, za rzecz niegodziwą, wybrał niebezpieczne pozostanie $z$ nimi ${ }^{10}$.

Ostatecznie - według Długosza - wzięty do niewoli Zawisza został ścięty przez jednego z dwóch Turków, spierających się, czyim jest jeńcem. Według dziejopisa:

Tak poległ znakomity rycerz, nie ustępujący nikomu spośród sobie współczesnych. Jego głowę przyniesiono sułtanowi tureckiemu, a martwe ciało ograbione ze zbroi pogrzebali mieszkańcy Raszki. (...) Przez długi czas Polska opłakiwała rycerza Zawiszę Czarnego jako swoją chlubę i ozdobę ${ }^{11}$.

Najprawdopodobniej staraniem wdowy, w krakowskim kościele Franciszkanów umieszczone zostało cenotafium Zawiszy w postaci zapewne drewnianej tablicy z wymalowanym na niej wierszem epitafijnym autorstwa Adama Świnki z Zielonej i prawdopodobnie dewocyjnym wizerunkiem rycerza ${ }^{12}$. Utwór Świnki, niewątpliwie najznakomitszy przejaw epiki w literaturze polsko-łacińskiej XV wieku, umieścił w Rocznikach Długosz. Do własnego komentarza przejął on od Świnki takie zaszczytne epitety rycerza, jak: „przykład cnót rycerskich i chluba Ojczyzny” oraz "honoru strażnik nieugięty”" "Zwróćmy uwagę, że według Świnki rycerz poległ w walce. W zakończeniu epitafium poeta zwraca się do ocalałych uczestników bojów pod Gołubcem,

(cyt. za: J. Domański, Filip Kallimach a Uniwersytet Krakowski, w: „Necessitas et ars”. Studia staropolskie dedykowane Profesorowi Januszowi Pelcoui, red. B. Otwinowska, A. Nowicka-Jeżowa, J. Kowalczyk, A. Karpiński, t. 2, Warszawa 1993, s. 92 (w przyp. 19 omówiona kwestia wariantowego zrozumienia końcowej frazy oryginału).

${ }^{10}$ Polska Jana Dlugosza, red. H. Samsonowicz, tł. tekstów J. Mruk, Warszawa 1984, s. 491. Por. relację J. Długosza o śmierci Spytka z Melsztyna w bitwie nad Worsklą, w której bohaterską śmierć rycerza dzicjopis przeciwstawił ucieczce Witolda z pola bitwy: „Gloriosior videtur michi Spitko palatinus morte, quam Vithawdus dux vita; preclare etenim ego secum actum reor, qui aliis per fugam vitam servantibus, ipse et presentis evi diuturnam gloriam et future beatitudinis perhenne bravium occupavit. Rogatus insuper et multifarie monitus ab Ediga Thartarorum duce, ne prelio futuro se misceret, aut si in proposito perseveraret, pileun ab eodem Ediga sibi destinatum in capite gestaret, quatenus huiusmodi insigni a militibus suis, quibus in districtissime preceperat, cognitus sernaretur pocius, quam violaretur, utrumque detestatus et perosus, vite mortem preferens nobilissimam mortem et que cum perennitate temporis celebrabitur, oppeciit, et gloriosior aliquanto occubuit quam viguit" (J. Długosz, Annales seu Cronicae incliti Regni Poloniae, lib. 10: 1370-1405, Varsaviae 1985, s. 228-229). Por. komentarz W. Dworzaczka (Leliwici Tarnowscy. Z dziejów możnowładztwa małopolskiego, wiek XIV-XV, Warszawa 1971, s. 117, przyp. 83), zwracający uwagę na fakt, iż jeszcze w 1403 roku nic miano pewności o śmierci Spytka. Zdanicm Dworzaczka, szczegóły podane przez J. Długosza pochodziły z tradycji ustnej. O zapisic w Roczniku Świętokrzyskim Nowym poświęconym bitwie nad Worsklą i polcgłym w niej rycerzom z zicmi krakowskiej i sandomierskicj, zob. M. Błaziak, op. cit., passim.

11 Polska Jana Ditugosza, loc. cit.

12 W dotychczasowcj literaturze utrzymywał sic̨ błędny pogląd pochodzący od Ryszarda Gansińca (Polonolatina II, „Pamiętnik Litcracki”, t. 21, 1924/25, s. 194), jakoby tckst tej objętości co utwór Świnki nie mógł zaistnicć w całości jako inskrypcja. Niesłuszności tego poglądu dowodzą wzmianki źródłowe o epigraficznych publikacjach nawet dłuższych utworów (jak na przykład epitafium Władysława Jagiełły pióra Grzegorza z Sanoka) na drewnianych „tablicach" (tabulae), w większości wypadków zapewne tożsamych z tak zwanymi epitafiami obrazowymi (publikację na ten temat przygotowuje autor niniejszego artykułu). Zob. Adami Porcarii Epitaphium Zavissii Nigri et Hedvigis Wladislai Jagellonis filiae, ed. Ch. Weysenhoff, Varsaviae 1961, wstęp edytorki, s. 11-12 i nota na s. 22.

13 Zob. Adami Porcarii Epitaphium..., op. cit., s. 29-30, w. 4 i 21, por. Polska Jana Dlugosza, op. cit., s. 492. 
akcentując idec̨ śmierci za wiarę i należnej za nią nagrody niebieskiej ${ }^{14}$. Wątek ten — jak już zaznaczaliśmy - będzie odtąd jednym $z$ wiodących w literaturze poświęconej wojnie i bohaterom, a umocni się $\mathrm{w}$ znacznej mierze dzięki rozmaitym utworom upamiętniającym śmierć Władysława III Jagiellończyka pod Warną (o których jeszcze poniżej).

W roku $1506 \mathrm{w}$ walce $\mathrm{z}$ Wołochami polegli dwaj bracia Strusiowie: Feliks i Jerzy. Ich śmierć prędko zyskała szeroką sławę. Pierwszy bodaj opisal ją Maciej Miechowita w Kronice Polaków $(1519,1521)^{15}$, choć prawdopodobnie jeszcze wcześniej poczęły krążyć o Strusiach pieśni. Stanisław Sarnicki bowiem w Ksiegach hetmańskich... podał, że rycerstwo

...śpiewają pieśni o Władysławie, co u Warny zginął, o bitwie z Prusy u Dambrowna [czyli grunwaldzkiej - M. J.], o Strusiech Jerzem i Szczęsnem etc., którzy w Wołoszech zginęli, o Mathiasu królu... ${ }^{16}$.

W innym jeszcze miejscu wspomniał Sarnicki, że o Strusiach śpiewane są „elegie, które Rusini nazywają dumami”" ${ }^{17}$. Marcin Kromer nazwał braci Strusiów „ozdobą szlachty ruskiej”"18 ,dwakroć pisał „o Szczęsnym i Jurku Strussowicach” Stryjkowski ${ }^{19}$.

Józefowi Bartłomiejowi Zimorowicowi zawdzięczamy przekaz o zaszczytnym pochówku braci w lwowskiej katedrze oraz poświęconej im choragwi nagrobnej. Byłaby ona (według obecnego stanu wiedzy) najstarszą u nas poświadczoną źródłowo tego rodzaju nagrobną formą upamiętnienia. Nadmieńmy tu tylko, że mimo znacznego rozpowszechnienia się w XVII wieku chorągwi nagrobnych zasadniczo były one traktowane jako forma nagrobka przysługująca szlachcie wojskowej, przy czym w szczególności poległym przysługiwała chorągiew o barwie szkarłatnej, oznaczającej przelanie krwi za Ojczyznę ${ }^{20}$. Zimorowic w nader poetyzowanym opisie śmierci

${ }_{14}$ Zob. Adami Porcarii Epitaphium..., op. cit., s. 31-32, w. 55 i n., por. Polska Jana Dlugosza, op. cit., s. 493.

15 Zob. Macicj z Micchowa, Chronica Polonorum, Cracoviac 1521 (recd. fototyp. Kraków 1986), s. CCCLXXIX.

16 S. Sarnicki, Księgi hetmańskie..., ks. X: O triumfiech i o tych rzeczoch (!), które po zwyciçstwie bywają, wyd. J. Kowalczyk, w: Renesans. Sztuka i ideologia..., red. T. S. Jaroszewski, Warszawa 1976, s. 336-342, zwł. s. 339. Por. Wojcicch Sarnicki [w istocie S. Sarnicki], Triumphus, hocest descriptio moris veterum..., Cracoviac 1581, przedr.J. Kowalczyk, w: Renesans. Sztuka $i$ ideologia..., op. cit., s. 342-348, zwł. s. 346, gdzie znajdujemy odpowiadający cytowanemu ustçp, szcrszy jednak o wzmiankę dotyczącą pieśni o bitwic pod Orszą: „Huiuscemodi laudibus mos decantandi laudes virorum illustrium adhibita lyra hactenus apud Polonos retentus fuit, quod testantur cantilenae illae de Vadislao Jagelonide, qui ad Vamam periit, de Vitoldo et bello Prutenico, de Strusiis germanis fratribus Felice et Georgio, pugna Orszensi, Matthiaeque regis illustria facta".

${ }^{17}$ „...elegiae, quas dumas Russi vocant” (cyt. za: S. Windakiewicz, Pieśni i dumty rycerskie XVI w., „Pamiçtnik Literacki”, t. 3, 1904, s. 347).

${ }^{18}$ W oryginale „decus Russicae nobilitatis”, por. M. Kromer, O pochodzeniu i dziejach Polaków - ksiegsi XXIX i XXX, w: idem, Mowa na pogrzebie Zygmunta I..., tł. i opr. J. Starnawski, Olsztyn 1982, s. 92-93, por. B. Paprocki, Herby rycerstwa polskiego, wyd. K. J. Turowski, Kraków 1858, s. 686.

19 Zob. M. Stryjkowski, Kronika polska, litewska, żmudzka i wszystkiej Rusi..., wyd. M. Malinowski, t. 2, Warszawa 1846, s. 329; por. idem, O początkach, wywodach, dzielnościach, sprawach rycerskich i domowych slawnego narodu litewskiego, żemojdzkiego i ruskiego..., z rękopisu wyd. J. Radziszewska, Warszawa 1979, s. 583.

20 Zob. S. Żółkicwski, Testament z r. 1606, w: idem, Pisma..., wyd. A. Biclowski, Lwów 1861, s. 178-179, nr 14, gdzic hetman polecał: „...jeślibym w potrzebic umarł, miasto aksamitu czarnego, który znaczy żałobę, nicch trumna przykryta będzie szarłatem, na znak wylania krwic dla Rzeczypospolitej, a to nie dla chluby żadncj, lecz dla pamiątki i dla pobudki drugich do cnoty i nicszanowania się dla Ojczyzny”. Por. K. Miaskowski, Kalliope polska na śmierć... Wojciecha Gajewskiego..., w: idem, Zbiór rytmów, wyd. A. Nowicka-Jeżowa, Warszawa 1995 (Biblioteka Pisarzy Staropolskich, t. 3), s. 312-315, zob. s. 313 (w. 15-16), gdzic Atena:

Sama i trumnç jego szkarłatem odziała,

Bo przystoi, by mężne tak wieziono ciała...;

Siedemnastowieczny kaznodzieja tak natomiast mówił o uczczeniu żołnierza: „Za tak odważne jego usługi 
Strusiów (zasadniczo wzorowanym na Kromerze) nieco ich wyidealizował, a Wołochów omyłkowo zapewne - zmienił w Tatarów ${ }^{21}$ :

Wrażymi szablami Tatarów otoczeni, gdy jeden drugiemu pragnął nieść pomoc, obydwaj nieśmiertelni, wspaniałe dusze oddali poprzez liczne rany. Ciała ich pokaleczone, posiekane, pocięte na cząstki tak bardzo, że żadną miarą nie można było ich rozeznać, w jednym zamknięto (schowano) sarkofagu, jeden kamień grobowy je przykrył przed wielkim ołtarzem katedry, skropiony łzami żałosnej matki i sióstr. Chorągiew zwieszającą się ze sklepienia, z wyobrażeniem obydwu — klęczących po stronach Ukrzyżowanego, strawił wkrótce pożar [w roku 1527 —M.J.], wszelako pamięć o tak bardzo bohaterskim towarzyszu, [pragnącym nieść pomoc bratu] ${ }^{22}$, krwią [obydwu] młodzieńców w duszach ludzkich zapisana, dotąd nie osłabła.

Podobnie jak w poetyckiej relacji o śmierci Zawiszy Czarnego, tak również w opisach śmierci braci Strusiów i w samej intencji ich upamiętnienia przed głównym ołtarzem katedry lwowskiej wybija się parenetyczne podkreślenie ofiarności i wierności wobec towarzysza walki.

Ród Strusiów w XVI wieku zasłynął szczególną walecznością. Bartosz Paprocki w Gnieździe cnoty... (1578) zanotował:

Dom Strusów z Komarowa, starodawny i zacny. Tych od Tatar zabitych 24 ludzi zacnych i mężnych ${ }^{23}$.

W wieku XVII wtórował Paprockiemu Szymon Starowolski w Wojownikach sarmackich ${ }^{24}$. Jan Kochanowski i Mikołaj Sęp Szarzyński w pamiątkowych wierszach poświęconych walecznym Strusiom (a w szczególności Stanisławowi) wysławiali ich jako idealnych sarmackich rycerzy ${ }^{25}$.

i niczwyciężoną miłość, co by mu też za wdzięczność oświadczyć? Podobno sic̨ tym kontentujemy, że po laccdemońsku, kości jego purpurą pokryjemy, abo po rzymsku, grób jaki z kosztownego marmuru, abo porfiretu wybudujemy" (A. Lorencowic, Kazania pogrzebne miane w różnych żałobnych okazyach..., Kalisz 1670, s. 39); por. I. Kozina, J. K. Ostrowski, Chorgguie nagrobne, w: Sarmatia semper viva -zbiór studiów ofiarowany przez przyjaciót prof. dr. hab. Tadeuszowi Chrzanowskiemu, Warszawa 1993, s. 91-138, zob. s. 133; M. Janicki, Choragwie nagrobne czyli nagrobki choragiewne i rycerski obrzadek pogrzebouv', „Studia i Materiały do Historii Wojskowości”, t. 39, 1998, s. 77-102, zob. s. 83.

${ }^{21}$ Podajemy w tłumaczeniu własnym, wg J. B. Zimorowic, Leopolis triplex, czyli kronika miasta Lwowa, w: idem, Opera..., cd. C. Heck, Lcopoli 1899, s. 108; por. idem, Historia miasta Lwowa..., tł. M. Piwocki, Lwów 1835, s. $176-177$; M. Janicki, op. cit., s. 90.

22 Rekonstrukcja sensu, jak siç zdaje, uszkodzonego w tym micjscu tekstu, dokonana w nawiązaniu do wersji wydarzeń przedstawionej przcz Kromera (O pochodzeniu..., op. cit.) i przyjçtej przez Zimorowica. W podstawie passus ten brzmi: „...memoria tamen paris adeo heroici, sanguine iuvenum animis hominum inscripta, nondum extenuata est”. Zob. J. B. Zimorowic, Leopolis..., loc. cit.

${ }_{23}$ B. Paprocki, Gniazdo cnoty..., Kraków 1578, s. 1033, por. ibidem, s. następną; idem, Herby..., loc. cit.

${ }^{24}$ Zob. S. Starowolski, Wojownicy sarmaccy..., tł. i opr. J. Starnawski, Warszawa 1978, s. 261; por. S. Okolski, Orbis Polonus..., t. 1, Kraków 1641, s. 488-439; K. Nicsiecki, Herbarz polski, wyd. J. N. Bobrowicz, t. 8, Lipsk 1841, s. $538-540$.

${ }^{25}$ Zob. M. Sęp Szarzyński, Pieśn VI: O Strusie, który zabit na Rastawicy od Tatarów roku Pańskiego [1571], w: idem, Rүtmy abo wiersze polskie oraz cykl erotyków, opr. i wst. J. Krzyżanowski, Wrocław 1973 (BN I 118), s. 35-37; J. Kochanowski, Nagrobek Stanislawowi Strusowi [Fr. III 49], w: idem, Fraszki, opr. J. Pelc, Wrocław 1998 (BN I 163), s. 146-147. 
Mimo triumfów odnoszonych w walkach z Tatarami długo przetrwała pamięć o klęsce wojsk polsko-litewskich w walce $z$ nimi pod Sokalem nad Bugiem w 1519 roku. Jak świadczy nie tylko przywoływany często epigram Jana Kochanowskiego Na sokalskie mogity, ale zapewne wcześniejsze jeszcze wywody Stanisława Orzechowskiego w jego Quincunxie... (1564), pamięć o porażce starano się spożytkować w świadomości społecznej, czyniąc z niej na wzór Termopil symbol ofiary złożonej Ojczyźnie.

Klęskę pod Sokalem Marcin Bielski przypisał: „uporowi ludzi młodych, a niesłuchaniu starszych" ${ }^{26}$, to znaczy szczególnie hetmana Konstantyna Ostrogskiego, który zalecał chwilowe wstrzymanie działań zaczepnych. Według Bielskiego w nieposłuszeństwie odznaczył się zwłaszcza dwudziestopięcioletni chorąży lwowski Fryderyk (Fredrusz) Herburt ${ }^{27}$ :

Fredrusza w tym winowano, iż był człowiek serca mężnego, chciwy ku potkaniu, przeto się z tym kwapił. Widząc Konstantyn, iż nie mogło być inaczej, acz nie chciwie, wszakże aby o sobie złej sławy nie puszczał, potkał się z nimi najpierwej; sparli jego ludzi prędko. Naszy potym potkawszy się z nimi dobrze, częścią iż mało ludzi było, częścią iż się sami zawalili na pogorzeliskach [miasteczka] w piwnice i w rozmaite doły, przemożeni od Tatar. Poległo tam wiele rycerstwa polskiego — prawie czoło wszytko okrom tych trochę, którzy mogli na Sokal zameczek ubieżeć. Fredrusz bacząc upadek naszych, jako był człowiek serca wielkiego, żywota ni zacz nie ważąc, rzekł: „Boże! Tego nie daj, abych przy mej miłej braciej gardła nie dał”. Rozpuścił koń ze wszego skoku dobrowolnie, jako jeden Kurcyjusz rzymski skoczył między nie z drzewem swoim, bił się z nimi, póki mógł sobą władać; tam między Tatary rozsiekan z krzykiem a z żałością więźniów, których natenczas dosyć nabrali ${ }^{28}$.

Znamienne, że i tu podobnie jak w przypadku Zawiszy Czarnego głównym motywem działania Herburta obok honoru była wierność wobec towarzyszy walki.

Stanisław Orzechowski natomiast, wspominając w Quinctuxxie... między innymi bohaterów spod Sokala, podkreślal również motyw patriotyczny, stwierdzając, że Herburt:

...gardło swe między drużyną wierną swą mężnie dał, okupując cześć króla swego, poczciwość swą a wolność Królestwa Polskiego krwią i śmiercią swą.

Wreszcie porównał go z Leonidasem pod Termopilami (do czego przyjdzie nam jeszcze powrócić) $^{29}$.

Z kolei Mikołaj Sęp Szarzyński zapewne około 1569-1570 roku ${ }^{30}$ opiewał Herburta jako przykład „umysłu statecznego i w cnotach gruntownego”, akcentując silnie poczucie osobistego

${ }^{26}$ Tak w wersji Kroniki z 1597 roku, opracowanej przez syna autora, Joachima; zob. M. Biclski, Kronika polska, wyd. K. J. Turowski, Sanok 1856, s. 1009, por. M. Biclski, Kronika to jest historia świata..., Kraków 1564, k. 417v.

${ }^{27}$ Urodzony w 1494 roku, chorąstwo lwowskic otrzymał w roku 1517. Zob. O. Easzczyńska, Ród Herburtów w' wiekach średnich, Poznań 1948, s. [84]-[85].

${ }^{28} \mathrm{M}$. Biclski, Kronika to jest historia świata..., k. 417v-418; por. idem, Kronika polska, loc. cit.

29 Zob. S. Orzcchowski, Wybór pism, opr. J. Starnawski, Wrocław 1972 (BN I 210), s. 568.

30 Zob. J. Błoński, Mikolaj Sęp Szarzyriski a początki polskiego baroku, Kraków 1996, s. 22, 31. 
honoru, czy właściwie palącej hańby z powodu podania tyłów nieprzyjacielowi i zamknięcia się w obwarowaniach, podczas gdy inni zginęli w walce. Utwór kończy modlitewny dwuwiersz (w. 47-48) włożony w usta wirtualnego przedstawiciela rycerstwa — „człowieka serca wspaniałego”:

\section{Z lepszym Ojczyzny szczęściem, wieczny Panie,}

Racz mi naznaczyć tak prętkie skonanie ${ }^{31}$.

Podobnie w pieśni o śmierci Stanisława Strusia, poległego w walce z Tatarami nad Rastawicą na zachód od Białej Cerkwi w 1571 roku, Szarzyński ponownie jako naczelny motyw działania wyeksponował zadośćuczynienie honorowi, któremu uwłacza uchodzenie przed nieprzyjacielem. Postawę bohatera poeta określił jako „czynienie dosyć i sławie, i cnocie”, każąc mu wypowiedzieć patriotyczny frazes, nawiązujący do idei naśladowania przodków i uwznioślający jego śmierć, „zwyklą” Strusiom, (jak czytamy w wariancie zakończenia utworu):

Nie wydam swych przodków, za Rzeczpospolitą

Upadnę ofiarą, da Bóg, znamienitą ${ }^{32}$.

Drugim obok Herburta rozsławionym bohaterem tragicznej bitwy sokalskiej był syn hetmana wielkiego koronnego Mikolaja Firleja (zm.1526), także Mikolaj ${ }^{33}$.

Zapewne mało jeszcze znany poeta polsko-łaciński, działający u schyłku XV i w pierwszej tercji XVI wieku, Jan Złotkowski, jest autorem jego epitafium ${ }^{34}$. Według świadectwa Bartosza Paprockiego utwór został opublikowany jako inskrypcja w kaplicy Firlejów lubelskiego kościoła Dominikanów $^{35}$. Fakt odnalezienia zwłok po bitwie potwierdza relacja Stanisława Orzechowskiego w Quincunxie... ${ }^{36}$, a ich pochówku w rodzinnym mauzoleum pośrednio także łacińskie epitafium pióra Jana Kochanowskiego, umieszczone w jego Foricoeniach (nr 18) ${ }^{37}$.

Epitafium przekazane przez Paprockiego rozpoczyna znamienny zwrot do przechodnia: „Jeśli tego, przechodniu, co w boju za Ojczyznę, za wiarę uległ przeznaczeniu [śmiertelnych] uważasz za sławnego [w oryg. pulchnım - M. J.]”. Następnie młody Firlej z powodu swej dzielności porównywany jest z Hektorem, wysławiany jako syn godny ojca, a zwłaszcza ten, który „padł w walce

\footnotetext{
${ }^{31}$ M. Sçp Szarzyński, Pieśn V: O Fridruszu, który pod Sokalem zabit od Tatarów roku Pańskiego 1519, w: idem, Rytmy abo uiersze polskie..., cd. cit., s. 35.

${ }^{32}$ Ibidem, s. 37 i wariant w. 33 i n. w przyp. Różnice poctyckicgo ujęcia miçdzy prawdopodobnic picrwotną redakcją Pieśni o Strusie (z rpsu BN BOZ 1049), która zapcwne krążyła w odpisach, a tekstem znanym z tomiku z 1601 roku ujawni w pełni przygotowywana obecnie w IBL PAN nowa naukowa edycja poezji Sępa Szarzyńskicgo, która ukażc siç w serii Bibliotcka Pisarzy Staropolskich IBL PAN. Tymczasem por. J. Bloński, op. cit., s. 249-250.

33 Zob. Polski stownik biograficzny, t. 7, Kraków, 1948-1958, s. 8-10 (aut. hasła: W. Pociecha).

34 Zob. Epitaphium Nicolai Firlej filii palatini Lublinensis campiductoris generalis Poloniae, w: Andreae Cricii carmina, cd. C. Morawski, Cracoviae 1888, s. 173, przyp.1; por. J. Wicsiołowski, Z kómickiego kodeksu „Corpus Cricianum”, „Pamiçtnik Bibliotcki Kórnickicj” 1979, z. 15, s. 245-246.

35 Zob. B. Paprocki, Herby..., s. 495.

${ }^{36}$ Zob. S. Orzechowski, ed. cit., s. 567.

37 Zob. J. Kochanowski, Epitaphimm Nicolai Firlei, w: idem, Dziela wszystkie. Wydanie pomnikou'e, t. 3, Warszawa 1884, s. 194: Epitaphium Nicolai Firlei:

Hace te urna exanimem servat, fortissime Firleu, Ipsius Martis cuspide perdomitum.

At tua laus vivet nullis obnoxia fatis,

Donec erunt hastae, spicula, signa, tubae.
} 
w obronie powszechnego dobra”, jako „kwiat rycerstwa i jego rzadka szlachetnością ozdoba”. Poeta nie wątpił wreszcie, że dzięki zbożnej waleczności (Marte pio) „szczęśliwy młodzieniec osiągnął miejsce w niebiesiech, a jego sława trwać będzie wiecznie"38.

W pochodzącym z tego samego mauzoleum epitafium Mikołaja Firleja, hetmana wielkiego koronnego, ojca bohatera spod Sokala, znalazło się wyraźne nawiązanie do śmierci syna poległego od tatarskiej strzały (Scythica sagitta) $)^{39}$.

Przypomnieć tu jeszcze należy, że prócz wspomnianego epigramu łacińskiego Jan Kochanowski poświęcił młodemu Firlejowi także polskie strofy, eksponujące — jak cytowany już wiersz Sępa — motyw „niewydania” przodków, niesprzeniewierzenia się ich postawie ${ }^{40}$ :

Więc i cnotliwy syn ojca nie wydał,

Ku czci dziedzicznej swoję własną przydał,

Bo, mężnie z placu spierając pogany,

Duszę cną wylał przez poczciwe rany.

(w. 15-18)

Pogrzebanie młodego Firleja w lubelskim mauzoleum rodzinnym przemawia również za prawdopodobieństwem informacji przekazanej przez Zimorowica o uroczystym pogrzebie bohaterów spod Sokala we Lwowie. Podał on bowiem, że po niefortunnej bitwie, pragnąc może nieco złagodzić gorycz porażki, co znamienitszym poległym (Herburtowi, Boratyńskiemu, Fredrze, Strusiowi) sprawiono pośmiertny triumf. Ciała ich uroczyście sprowadzono do Lwowa i pochowano w różnych kościołach ${ }^{41}$. Być może kontynuowano tym samym pewną już tradycję, której zaczątkiem mógł być pochówek braci Strusiów w katedrze lwowskiej. Znamienne zresztą, że znaczna część świadectw związanych z pochówkami rycerskimi pochodzi z samego Lwowa ${ }^{42}$.

W 1613 roku skonfederowani pod Cieklińskim żołnierze oprócz — jak określił to Zimorowic „skarbów książąt moskiewskich” przywieźli do Lwowa w zasmołowanych kłodach ciała swoich

38 Zob. Andreae Cricii Cammina..., op. cit.:

Si quem pro Patria, pro religione viator, Inque armis pulchrum fata subire putas,

En tibi magnanimum iuvenem sic fortiter actum

Et dignum Hectorea condicione legi

Clara palatini suboles, Firleia proles, Inclita et insignis digna propago patris,

Communem in pugna cecidit tutando salutem, Cum numero invicti praevaluere Scythae.

Fuderuntque suo multo cum sanguine robur Militiae et rarum nobilitate decus.

Felicem iuvenem caelesti sede potitum Marte pio et eius fama perennis erit.

Por. S. Starowolski, Monumenta Sarmatarum, Cracoviae 1655, s. 728; Biblioteka PAN w Kórniku, rps 243, k. 299v.

${ }^{39}$ Zob. S. Starowolski, op. cit., s. 727-728.

${ }^{40}$ Zob. J. Kochanowski, Do jego miłości pana Mikołaja Firleja (Fragmenta albo pozostale pisma [15]), w: idem, Dziela polskie, opr. J. Krzyżanowski, t. 3, Warszawa 1955, s. 30-31.

${ }^{41}$ Zob. J. B. Zimorowic, Leopolis..., op. cit., s. 114: „Nobilium filii praecipue Herburtii, Boratini, Fredrii, Strusii, Leopolim conducti, militari pompa per aedes sacras conditi sunt".

${ }^{42}$ Por. M. Janicki, op. cit., s. 80, 89-94, 96-98. 
poległych i zmarłych podczas wyprawy moskiewskiej komilitonów. Zostały one złożone w nieukończonym jeszcze kościele Bernardynów, w krypcie w prawej nawie, przed ołtarzem dedykowanym św. Michałowi Archaniołowi - patronowi rycerstwa i ziem ruskich. Według Zimorowica pogrzeby miały charakter, typowej już w owym czasie dla rycerskiej pompa funebris, inscenizacji triumfu śmierci: $z$ odwracaniem niesionych choragwi, łamaniem włóczni, ciskaniem tarcz i druzgotaniem pancerzy. Po uroczystościach zawieszano w kościele choragwie nagrobne, upamiętniające zwłaszcza wojenne czyny poległych. $Z$ czasem ustaliła się też tradycja zawieszania przy wspomnianym ołtarzu Michała Archanioła autentycznych elementów uzbrojenia - panopliów w charakterze wotów. Kościół lwowskich Bernardynów stał się przed połową XVII wieku nekropolią ruskiej szlachty wojskowej $^{43}$.

W roku 1621 walczyli pod Chocimiem dwaj bracia Rudominowie-Dusiatscy, pochodzący z Nowogródzkiego: Jan i Jerzy. O Janie Rudominie u Kaspra Niesieckiego czytamy:

...najprzód chorąży, a potem kasztelan nowogródzki; pod Chocimem odwaga się jego pokazała, już natenczas rotmistrza usarskiego, kiedy z drugimi trzema chorągwiami, sześćdziesiąt tysięcy Turków, na obóz nasz nacierających, odpędzil; tam brata swego rodzonego zabitego utracił, sam w rękę raniony; pobitych drugich $\mathrm{w}$ tejże okazyi ciała, w nowogródzkiej parafiji solennie pogrzebł, z marmurowym nagrobkiem, i z swojej fortuny wieczną fundacyję uczynił, aby co tydzień za dusze tychże pobitych msza się święta odprawowała ${ }^{44}$.

Pomnik wystawiony za sprawą Rudominy w roku 1643, szczęśliwie dotrwał do naszych czasów. Jest to zabytek jedyny w swym rodzaju ${ }^{45}$. W prostym profilowanym obramieniu umieszczone zostały dwie tablice inskrypcyjne i dwa reliefy. Relief górny przedstawia Marię Pannę z Dzieciątkiem w półpostaci, wyłaniającą się z obłoków. W lewym ręku trzyma Ona wieniec „koronę niebieska”, w prawym zaś różańce, które, jak wierzono, podaje duszom czyśćcowym, by tym sposobem wybawić je z udręki. Relief dolny jest przedstawieniem niezwykłym i zapewne nieposiadającym odpowiednika ${ }^{46}$. (Programowo wiąze się ono $z$ opisanym wizerunkiem Marii, której kult znalazł także wyraz w inskrypcji pomnika). W zagiętym w półkole rzędzie klęczy dziesięciu identycznie odzianych w strój wojenny „rycerzy”, z koncerzami u boku. Wszyscy „towarzysze”, prócz jednego, mają dłonie złożone w geście modlitewnym. Dziewięciu adorantów, od lewej licząc, jest bez głów. Na ich miejscu, na obciętych szyjach, widać

${ }^{43}$ Zob. ibidem, s. 93, 96-98.

${ }^{44}$ K. Niesiccki, op. cit., t. 8, s. 184-185.

${ }^{45}$ Omówił go pokrótce Tadcusz Bernatowicz, który części zagadnień omawianych w niniejszym artykule poświęcił ostatnio nicco uwagi z punktu widzenia historyka sztuki (Śmierć nycerza kresowego i jego „sepulchrum”, „Studia muzcalne”, z. 19, Poznań 2000, s. 66 i fig. 8 na s. 67).

${ }^{46}$ Ponieważ relicf jest już dziś nieco zatarty, zwietrzały i otłuczony, odczytując treść przedstawienia posługujemy się nie tylko fotografią z początku lat dwudziestych (ze zbioru Instytutu Historii Sztuki PAN), lecz równicż XIX-wicczną ryciną zamieszczoną w: J. K. Wilczyński, Album wileńskie..., poszyt I, Wilno 1846. Fotografia zabytku, ukazująca jego stan na początku lat osiemdzicsiątych XX w., znajdujc się w: [N. F. Wysockaja,] Plastyka Belarusi XII-XVIII stagoddzjav, Minsk 1983, tabl. 165 (w opisie błędna data powstania pomnika). 
jakby małe serca. Dwaj bezgłowi rycerze wspierają ręce na koncerzach wbitych przed nimi w ziemię. Czwarty od lewej spośród makabrycznych adorantów lewą dłoń złożył na piersiach w geście pokory i oddania, prawą zaś, opuszczoną i otwartą ku widzowi, zdaje się wskazywać leżących u jego kolan zabitych towarzyszy. Przed klęczącymi bowiem ukazał rzeźbiarz ciała leżące na brzuchu i na wznak (dwa z nich bez głów), między nimi zaś walające się odrąbane głowy, wśród których widać jeszcze polską czapkę i hełm z piórem. Autorem programu pomnika był zapewne sam jego fundator. Należy go utożsamiać $z$ adorantem pierwszym od prawej. Nieco odsunięty od pozostałych, z szyszakiem na głowie i różańcem zwieszonym z lewego naręcza zdaje się zwracać ku wyobrażeniu Marii w obłokach, jakby w modlitwie za poległych towarzyszy. Ich nazwiska wykute zostały u dołu pola górnej inskrypcji pomnika, ponad opisanym reliefem.

Nowogródzkie przedstawienie unaoczniać miało idę̨ ofiary życia w walce $z$ wrogiem wiary jako przyczynku do łaski zbawienia. Szczególnie godne podkreślenia wydaje się jednak to, że pomnik ufundowany przez Rudominę jest piękną pamiątką żolnierskiego braterstwa i przyjaźni.

Sprowadzanie zwłok poległych wynikało z bardzo silnej w kulturze staropolskiej idei grobu rodzinnego, spoczywania obok przodków lub po prostu pragnienia godnego pochówku bliskiego, co uwidoczniają omówione wyżej przykłady.

W niecierpiących zwłoki okolicznościach wojennych nie tylko odnalezienie i identyfikacja ciał, ale zwłaszcza ich eksportacja w zasmołowanej trumnie okazywała się jednak nader często niemożliwością i należy ją uznać raczej za wyjątkową ${ }^{47}$. Zazwyczaj polegli grzebani byli wprost na pobojowisku bądź opodal w grobach zbiorowych.

${ }^{47}$ Jak widzicliśmy to na przykładzic Zawiszy Czarnego, mimo iż — jak wynika z relacji Długosza — znano micjscc jego pogrzebania (choć prawdopodobnic była to mogiła zbiorowa), ostatecznic poprzestano na sprawicniu mu cenotafium w krakowskim kościcle Franciszkanów. Podać jednak można szereg przykładów cpitafiów świadczących o dokonancj cksportacji zwłok z pola bitwy. Syn Zawiszy, Jan z Garbowa, który zginął w bitwic pod Chocimicm w 1454 roku pochowany został w kościcle w Kole, zob. P. Mrozowski, Polskie nagrobki gotyckie, Warszawa 1994, s. 173-174. Jan z Rytwian Zborowski, poległy pod Orszą w 1514 roku, pochowany został w kościcle Bcrnardynów w Wilnic (,, fortissimae pugnantis, occisi atque huc honorificentissimae delati, corpus cubat in isto tumulo" - B. Paprocki, Herby..., op. cit., s. 145; por. K. Nicsiccki, op. cit., t. 10, Lipsk 1845, s. 129). Memoria Marcina i Macicja Sobicjuskich w Staroźrebach w Płockiem była zapewne w cz̨̨ści cenotafium. Marcin zginąć miał jako dowódca obrony Dobrego Miasta, zdobytego przez wojska wielkiego mistrza Albrechta 14 listopada 1520 roku, Maciej zaś w bitwie pod Mohaczem w roku 1526 u boku króla Ludwika (zob. B. Paprocki, op. cit., s. 401-402; S. Starowolski, op. cit., s. 491; K. Nicsiecki, op. cit., t. 8, Lipsk 1841, s. 427). W 1581 roku podczas szturmu Pskowa padł Mikołaj Czcrny. Jak wynika z przckazu Paprockiego, jego ciało zostało sprowadzone do ojczyzny. Podwójnym cpitafium: na nagrobck i prawdopodobnic na choragiew nagrobną uczcił Czcrnego Samucl Wolff, rektor szkoły lcwartowskicj (lubartowskicj). Epigramat jemu i jego bratu Adamowi pośwį̨cił też we Fraszkach (III 83) Jan Kochanowski (ed. cit., s. 167, Nagrobek du'iema braciej, por. K. Nicsiccki, op. cit., t. 3, Lipsk 1839, s. 249). Warto wskazać jeszcze: cpitafium Stanisława Wybranowskicgo w Samborze u dominikanów, poległego w wyprawic chocimskiej 1621 roku (zob. S. Starowolski, op. cit., s. 533; K. Niesiccki, op. cit., t. 9, Lipsk 1842, s. 450) oraz Wojciecha Srzcdzińskicgo vel Średzińskicgo w Brzcżanach poległego w walce z Tatarami pod Baworowem w 1623 roku (zob. S. Starowolski, op. cit., s. 484, por. K. Nicsiccki, op. cit., t. 8, s. 468). Zapewne pochówek w którymś z krakowskich kościołów znalazł Mikołaj Kicrmański, który padł pod murami stolicy, broniąc jej przed wojskami Maksymiliana Habsburga 23 listopada 1587 roku. Epitafium uczcil go Joachim Biclski (Nagrobek Mikołajowi Kiernańskiemu sławnemu rotmistrzowi pieszemu, zob. J. Kapuścik, W. J. Podgórski, Poeci żolnierzom 1410-1945. Antologia wierszy i pieśni żolnierskich, Warszawa 1970 [dalcj: Poeci żolnierzom], s. 73 i komentarz na s. 575-576). Nic umiemy powicdzicć, gdzie pochowany został poległy pod Byczyną 24 stycznia 1588 roku dowódca kozacki Hawryło Hołubck (Gołąbek), uczczony wierszami przez Joachima Biclskicgo (Nagrobek Hawryle Holubkowi wodzowi kozackiemu niepospolitemu) i Stanisława Grochowskicgo (Holubek) - zob. Poeci renesansu. Antologia, opr. J. Sokołowska, Warszawa 1959, s. 156, 250 i komentarz na s. 432-433. 
Po bitwie grunwaldzkiej Władysław Jagiełło nakazał odszukać ciało wielkiego mistrza i wraz ze zwłokami innych jeszcze dostojników zakonnych odesłać do Malborka. Jak następnie relacjonuje Długosz, polecił te $\dot{z}$, by:

...ciała innych dowódców oraz znakomitych i szlachetnych osób pochowane zostały w drewnianym kościele w Stębarku, w którym to kościele pogrzebane zostały również ciała poległych po stronie polskiej, odnalezione i rozpoznane przez znajomych i bliskich; zwycięzcy nie otrzymali pochówku godniejszego anizeli zwyciężeni ${ }^{48}$.

Ponad grobami na pobojowiskach usypywano najczęściej wyniosłe kopce okładane darnią. Określano je najczęściej jako mogity ${ }^{49}$, kurhany ${ }^{50}$ bądź z łacińska jako molles, scopuli. Najgęściej były one rozsiane na południowo-wschodnich kresach dawnej Rzeczypospolitej, o czym pisał już Stanisław Sarnicki ${ }^{51}$.

Jak wszelkie formy nagrobnego upamiętnienia w dawnej kulturze, tak też mogiły-kurhany nad grobami poległych pełniły istotną funkcję parenetyczną. Nie tylko więc oznaczały miejsca bitew, ale przede wszystkim przypominały i napominały. „Kopce raczej niż mogiły przed miastem Sokalem widniejące i ożywiające gorzką pamięć tej klęski” - pisał Zimorowic o słynnych „Sokalskich mogiłach” z 1519 roku, które na rozkaz wodza usypać mieli nad grobami większości swych komilitonów sami żołnierze ${ }^{52}$. Sławę tych mogił utrwalił Jan Kochanowski w znanym - i wspomnianym tu już -

\footnotetext{
48 Tlumaczenic własne. W oryg.: „Corpora vero aliorum commendatorum et illustrium ac nobilium personarum, ut in ecclesia parochiali lignea in Timbarg [tj. Tannenberg = Stębark - M. J.] sepelirentur, (..) providit (...). In qua quidem ecclesia et corpora eorum qui in Polonico exercitu ceciderant, a notis suis et charis perquisita et inventa, fuere sepulta, nec splendidiorem humacionem nacti sunt victores quam victi" (J. Długosz, Annales seu Cronicae incliti Regni Poloniae, lib. 10-11: 1406-1412, Varsoviae 1997, s. 120-121). Por. Cronica conflictus Wadislai regis Poloniae cum Cruciferis anno Christi 1410, z rçkopisu Biblioteki Kórnickicj wyd. Z. Celichowski, Poznań 1911, s. 30; J. Okulicz, Spratuzdanie z badan na stanowisku 9 (Stębark), „Rocznik Olsztyński”, t. 4, 1961/1962 (1962). Grobu, o którym pisał Długosz, a który mógł zawicrać około 300 ciał, nic udało sic̨ wówczas odnaleźć, zob. ibidem, s. 291 i 303 . Mogiły zbiorowe poległych odkryto natomiast wśród ruin kaplicy wzniesioncj przez Zakon na polu bitwy około 2 lata po nicj. Zob. R. Odoj, Sprawozdanie z badań na stanowisku 1 (kaplica), op. cit., s. 242-251, por. Z. Rajcwski, Badania na polach Grunwaldu, op. cit., s. 201; S. M. Kuczyński, Poklosie Grunwaldu, op. cit., s. 404.

49 Zob. Slounik polszczyzny XVI wieku, t. 14, Wrocław 1982, s. 572.

50 Zob. ibidem, t. 11, Wroclaw 1978, s. 579.

sı „Molles, co zowiemy mogiły, jakich na Podolu siła, które zową kurhanami. Abo i przed Krakowem Rçkawka, Nogawka, przy których też szczepili(!?)”. Zob. Sarnicki, Księgi hetmańskie..., cd. cit., s. 341, por. W. Sarnicki, op. cit., s. 347 i w ninicjszym tekścic z przyp. 55 i 69.

52 „Scopuli potius, quam tumuli, citra Socalum oppidum superstantes et acerbam memoriam cladis huius refricantes” — J. B. Zimorowic, Leopolis. .., op. cit.; zob. idem, Historia miasta Lwowa..., op. cit., s. 186. Por. wicrszowane nagrobki N. N.: Tym co pod Guzowem
}

Choć na Scjmic nicpamiçć o tym uczyniono,

Naszych przecie dlatego mogił nic znicsiono,

Aby czasom potomnym to opowiadaly:

Tu się były złe dzieci z ojcem rozigrały. Tym co pod Chocimiem

Gościu, mijając tędy, widzisz te mogiły,

W tym micjscu dwa narody z sobą graniczyły:

Turcy i cni Polacy, i tu chłostç brali

Bisurmańcy, ażeby kopce pamiçtali. 
epigramie z Fraszek (I 77) Na sokalskie mogity, a także w ustępie cytowanego powyżej wiersza Do jego mitości pana Mikotaja Firleja z Fragmentów 53

We fraszce, nawiązując zapewne do przypisywanego niegdyś Simonidesowi dystychu ku czci Spartan poległych pod Termopilami ${ }^{54}$, Kochanowski, zastosowawszy figurę prozopopei, kazał samym poległym i pogrzebanym pod Sokalem zwracać się do rodaków z napomnieniem (oratio e tumulo). Natomiast w wierszu Do... Mikolaja Firleja..., po cytowanych wierszach poświęconych poległemu pod Sokalem przodkowi (w. 15-18), następne wiersze (19-24) można by wyodrębnić jako osobny epigramat ku czci wszystkich tam poległych, jakby wtrącony w wiersz Do Firleja, a będący swego rodzaju odpowiednikiem epigramu sokalskiego z Fraszek. Jak tamten jest prozopopeją samych poległych, tak tu mamy do czynienia $z$ apostrofą do nich, zawierającą zapewnienie, że sława ich męstwa i śmierci trwać będzie wiecznie w zbiorowej pamięci.

Szlachetne roty, których martwe głowy

Chowa i chować będzie brzeg Bugowy,

Sławna śmierć wasza, sławne męstwo wszędzie!

A żadny wiek tak niewdzięczny nie będzie,

Aby posługi wasze znakomite

Były potomkom przyszłym kiedy skryte.

$$
\text { (w. 19-24) }{ }^{55}
$$

(J. Gawiński, Sielanka i różne nagrobki z przydatkiem innych autorów..., Kraków 1650, k. D4; E1v). Jakub Sobicski zwracał się do poległych w wyprawie chocimskiej: „Waszc imiona staną się ozdobą tcj Korony pamiçtnc, waszc mogiły będą wyniosłymi trofeami nieśmiertelnej sławy i wystawnymi ołtarzami krwawej za Ojczyznę ofiary" (J. Sobicski, Diariusz wyprawy chocimskiej, w: Pamiętniki o wyprawie chocimskiej r. 1621.., wyd. Z. Pauli, Kraków 1853, s. 183-184; por. T. Bernatowicz, op. cit., s. 66-67 i w niniejszym tekścic przyp. 55). Stanisław Żółkiewski w mowic z 1618 roku: Dziękowanieza wielkq butawę, wspomina jako pobudzające ducha „walecznychludzi śmicrtelne mogiły”-zob. S. Żółkicwski, Pisma..., op. cit., s. 397 i 464, gdzie w Pobudce do cnoty (omówionej ponizej) jeden z rozprawiających Spartan wypowiada następujące słowa: „Gdy tak dla Ojczyzny mężnymi śmierciami pomrzem, potomni przez groby nasze przysięgać będą".

${ }_{53}$ Zob. J. Kochanowski, Fraszki, ed. cit., s. 39; idem, Dziela polskie, loc. cit.

${ }^{54}$ Przekład Jana Czubka, w: Lirycy greccy (doby klasycznej), tł. J. Czubek, Kraków 1882, s. 89:

Przechodniu! powiedz Sparcie: tu leżym, jcj syny,

Prawom jej do ostatniej posłuszni godziny.

Nowsze tłumaczenia:

Zanieś, wędrowcze, tę wieść mic̨dzy Lacedemonu micszkańców: Legliśmy tutaj, by ich słowu posłuszni się stać.

(tt. W. Klinger, w: Antologia liryki greckiej, opr. W. Steffen, Wrocław 1955 (BN II 92), s. 176, za wskazanic dwóch powyższych tłumaczeń składam podziękowanie dr. Jackowi Wójcickiemu);

Gościu, oznajmij Spartanom, że tutaj polegliśmy w boju,

Zawsze gotowi strzec świętych ojczyzny swej praw.

(tł. J. Wikarjak, w: idem, Gramatyka opisowa języka lacińskiego, Warszawa 1978, s. 155).

${ }^{5 s}$ J. Kochanowski, Dziela polskie, op. cit., t. 3, s. 30. Por. P. Napolski, Druga givaltowna i szczęsliva potrzeba najjaśniejszego Whadystawa królewica polskiego z sultanem Osmanem cesarzem tureckim, pod Chocimem zamkiem na polach woloskich nad rzekq Dniestrem odprawowana... w roku 1621, w: Poeci żolnierzom, s. 102-111. Motto utworu: „Beati qui pro Patria fortiter dimicantes in acie cadunt, sempitemam enim memoriam cunctis divitiis praestantiorem consequntur". W apostrofie do polcgłych czytamy (w. 291-292; 295-312):

Nieśmiertelnej pamięci dostojni synowie,

Któż miłość waszę przeciw Ojczyźnie wypowie? (..)

Nie zajdziecie w głębokie nigdy zapomnienie 
Jakkolwiek $\mathrm{w}$ podtrzymaniu tej pamięci zasadniczą rolę odegrały omawiane tu pomniki literackie, to niemałą także lokalne przekazy ustne, związane z polami bitew.

Cytowane wyżej wiersze Kochanowskiego przemawiają za wiarygodnością tradycji, która przetrwała w samym Sokalu zapewne przynajmniej do lat czterdziestych XX wieku: o pogrzebaniu części poległych w bitwie nad brzegiem Bugu, w miejscu oznaczonym figurą stojącą na niewielkim kopcu-mogiłce przy późniejszym moście kolejowym ${ }^{56}$. W pobliskiej Poturzycy (należącej do Dzieduszyckich) wskazywano natomiast mogiłę, która według niezbyt wiarygodnej tradycji, powstałej być może dopiero po pierwszym wznowieniu tomiku Sępa Szarzyńskiego w 1827 roku, miała oznaczać miejsce śmierci Fryderyka Herburta 57.

We wsi Rohoźna, leżącej nad bezimiennym dopływem Rastawicy, uchodzącym w pobliżu wsi Buki, jeszcze w XIX wieku wskazywano mogiłę Stanisława Strusia ${ }^{58}$. Za tą tradycją przemawia zresztą znowu formuła epigramu Kochanowskiego, ułożonego — podobnie jak epigram sokalski - jako prozopopeiczna przemowa z mogily (oratio e tumulo) ${ }^{59}$.

W związku z podkreślanym wyżej wręcz kultem pochówku obok przodków czy przynajmniej w ziemi ojczystej, najwięcej bólu sprawiać musiała pozostałym przy życiu, krewnym, świadomość niepogrzebania ciał bliskich, a niekiedy $\mathrm{i}$ ich pohańbienia.

Ani was lata długie puszczą w zamilczenie,

Bo jeśli Rzym z śmiałości sławi Kurcyjusza

I z szczęśliwych potyczek chwali Pompcjusza,

Grecyja Achillesa, Ajaksa, Nestora,

Ilium potężnego żołnierza Hektora -

Tedy i Sarmacyja postępku takiego

Poda ludziom pamiątkç wieku potomnego,

Aby waszej ku bracicj tak krwawej przysługi,

Miłości ku Ojczyźnic był świadkicm wick długi,

Ciało zaś w polu z darnia mogiłą pokryje

I na nagrobku słowa takowe wyryjc:

„Tu leżą mężów polskich pozostałe kości,

Którzy polegli strzegąc ojczystych wolności;

Gdy Turcy z wojski swymi na nich nacierali,

Tu im potçżnie odpór długo zakładali. Boże,

użycz im za to Królestwa wiccznego,

Bo pomarli pokoju broniąc ojczystego".

(Poeci żotnierzom, s. 107-108).

Na marginesie przy epitafium argument: Nagrobek żolnierzom pobitym (zob. op. cit., s. 585, przyp. 307). Por. w ninicjszym tekścic przyp. 52, gdzie cytowana jest wypowiedź Jakuba Sobieskicgo.

${ }^{56}$ Zob. B. Sokalski, Powiat Sokalski pod względem geograficznym, etnograficznym, historycznym i ekonomicznym, Lwów 1899, s. 346, nr 1: „...po lewej ręce wyjeżdzając od dworca kolejowego w Sokalu”. Zdanicm autora mogitka kryje kości młodzieży polskiej. Ostroga pochodząca z tej mogiły znajdowała się w Muzeum Zakładu Narodowego im. Ossolińskich we Lwowie (por. ibidem).

57 Op. cit., s. 347, nr 4: „Figura w Poturzycy na wzgórzu za dworem. Miano tu w czasie restauracji natrafić na mnóstwo kości ludzkich. Czytałem w jakiejś broszurze ruskiej, że był na niej rok 1519 oznaczony. Słyszałem niczym nie poparte zdanie, że w tym miejscu miał polec Herburt Fryderyk, co też z zastrzeżeniem notuję". Znamienne jednak, że zanotowane przez Sokalskiego podanie miejscowe nie stoi w sprzeczności z cytowanym przekazem Zimorowica o odnalezieniu ciała między innymi Herburta i pochowaniu go w którymś z kościołów lwowskich. Por. w niniejszym tekście przyp. 41.

58 Zob. Slownik geograficzny Królestwa Polskiego i innych krajów slowiańskich, t. 9, Warszawa 1888, s. 530, 696; t. 1, Warszawa 1880, s. 459.

${ }^{59}$ Zob. w niniejszym tekście przyp. 25. 
Jak dowodzi tego chociażby cytowana wzmianka Sarnickiego o pieśniach żołnierskich, przez cały wiek XVI, a dzięki między innymi dramatowi szkolnemu także XVII i XVIII wieku ${ }^{60}$, żywa pozostała pamięć o wyprawie warneńskiej i śmierci młodego władcy, który, jak uznano, rzucił się do straceńczej walki w imię obrony wiary ${ }^{61}$.

Szczątków Władysława Warneńczyka, pohańbionego przez odcięcie mu głowy, nie odnaleziono. Przypomnieć warto, iż według nader wątpliwej tradycji na miejscu śmierci króla sam Murad II polecił wznieść kolumnę z napisem mówiącym o śmierci Władysława jako karze Bożej za złamanie przysięgi - rzekomo tym samym, który w XVI wieku krążył po Europie w odpisach, a uznany został za utwór Jana Pannoniusa ${ }^{62}$.

Jan Kochanowski w niedokończonej próbie epickiej, znanej pt. Wtodzistaw Warneńczyk, wysławiając jego bohaterską śmierć za wiarę, stwierdzał:

Z dobrych dobrzy się rodzą, syn ojca nie wydał,

Lecz ku sławie dziedzicznej i swą własną przydał,

Król dwu koron Włodzisław, bo, bijąc pogany,

We krwi nieprzyjacielskiej upadł zmordowany

Wpośrzód ziemi tureckiej; jego poświęcone

Kości nie są w ojczystym grobie położone:

Grób jego jest Europa, słup — śnieżne Bałchany,

Napis — wieczna pamiątka między krześcijany.

$$
\text { (w. } 73-80)^{63}
$$

${ }^{60}$ Zob. B. Judkowiak, Whadystaw Warneńczyk bohaterem dramatu polskiego XVII i XVIII wieku, „Balcanica Posnanicnsia”, t. 8, 1997, s. 185-199.

${ }^{61} \mathrm{~W}$ utworze Plangite me coeli, autorstwa zasadniczo antypolsko nastawioncgo Mikołaja Petschachera (jest to jedyny jego utwór pozbawiony kalumni na Jagiellonów), a napisanym zapcwne w latach 1445-1452, w prozopopciczncj apostrofic do Chrystusa król oświadcza, żc składa Mu swe życie w ofierze, odrzuciwszy propozycję salwowania się ucicczką; zob. J. Nowak-Dłużewski, Okolicznościow'a poezja polityczna w Polsce. Średniourecze, Warszawa 1963, s. 75-77 i przyp. 3 na s. 136; A. F. Grabski, Wiersze o klęsce warneńskiej. $Z$ dziejów okolicznościowej poezji politycznej w Polsce XV w., „Prace Polonistyczne", seria XXIII, 1967, s. 26-54, s. 27-33, tam też krytyczne uwagi do wywodów J. Nowaka-Dłużcwskicgo. Występowanie motywu złożenia życia w obronic wiary w oficjalncj propagandzic dynastyczncj dokumentuje między innymi treść mowy królewicza Kazimierza Jagicllończyka, wygłoszoncj w 1472 roku przed legatem papieskim, zob. Codex epistolaris saeculi decimi quinti, t. 1, Kraków 1876, s. 340-341, por. J. Skoczck, Wychowanie Jagiellonów, Lwów 1932, s. 93. Por. tcż: A. F. Grabski, op. cit., s. 41-42, gdzic omówione zostało wystąpienie Jana Ostroroga przed papieżem Pawłem II w roku 1467.

62 Tekst zapisany przez pisarza węgierskiego Piotra Révaia:

Romulidae Cannas, ego Vamam clade notavi

Discite mortales non temerare fidem.

Me nisi pontifices iussissent rumpere foedus

Non ferret Scythicum Pannonis ora jugem.

Cyt. za: I. Czamańska, Bitwa pod Warnq w tradycji wegierskiej i balkańskiej, „Balcanica Posnanicnsia”, t. 8, 1997, s. 180-181, por. U. Kaczmarek, Warneńskie pole - dzicje pomnika, ibidem, s. 210, gdzie informacje o funkcjonowaniu przytoczonego wyżej epigramu i jego następujący przekład: „Rzymianie Kanny, ja Warnę wsławiłem, uczcic się śmiertelni dochowywać wiary. Gdyby kapłani nie nakazali mi złamać traktatu, nie nosiłaby Pannonia jarzma Scytów". Warto przypomnieć, że czterowierszowe epitafium króla podał flandryjski kronikarz Adricn de But, cysters z klasztoru w Dunes k. Furnes (zm. 1488). Tckst został przez autora dopisany do ukończoncjjuż kroniki. Zob. A. F. Grabski, op. cit., s. 54 .

${ }^{63}$ J. Kochanowski, ed.cit., t. 3, s. 40, por. Proporzec albo hołd pruski, w. 145-148; t. 1, s. 90, Picśń I 10, w. 51-52; ibidem, s. 283. Por. O śmierci Wadyslawa króla polskiego dwaj tylko szlachta polscy powracajacy spod Warny opowiedaja, w: Poeci żotnierzom, s. 59-60. 
Zastosowany przez Kochanowskiego topos Europy-grobu być może w pierwiastkowej formie znajdujemy u Tukidydesa w cytowanym na wstępie epitafionie Peryklesa:

Grobem sławnych mężów jest cała ziemia, sławę ich głoszą nie tylko napisy na stelach w ich ojczystym kraju, lecz nawet na obczyźnie żyje o nich pamięć, nie pisana na pomniku, lecz w duszach ludzkich (II 43$)^{64}$.

Pochodzące z wieku XVII - wieku wojen - epigramy (Jana Gawińskiego, Zbigniewa Morsztyna, Wespazjana Kochowskiego) odmalowują makabryczny obraz pobojowiska, na którym niepogrzebane ciała stają się pastwą dzikiego ptactwa, wilków i psów ${ }^{65}$.

W anonimowym czterowierszu Dobremu żotnierzowi nagrobek na placu cale pozostatemu poległy skarży się tymi słowy:

Mój to trup na tym polu od psów rozwleczony,

Na którym za Ojczyznę jestem położony.

O, jako żeś niewdzięczna, ma Ojczyzno miła,

Żeś mię przynajmniej ziemią trochę nie przykryła ${ }^{66}$.

Pragnąc pomniejszyć wrażenie pohańbienia ofiarnego żołnierza, poeci uciekli się do innego jeszcze, niż ów wywodzący się być może od Tukidydesa, antycznego konceptu: nieba okrywającego poległych. Pochodzi on zapewne z VII księgi Farsaliótw Lukana (w. 819), gdzie wyrzucał on Cezarowi, że ten po bitwie pod Farsalos zabronił kremować i grzebać wrogów, by wreszcie na koniec nagany stwierdzić:

...chłonie wszystko ziemia,

Co zrodziła; niebem przykryty, kto nie ma pochówku ${ }^{67}$

Wespazjan Kochowski w pieśni XVII Lyricorum polskich księgi I, poświęconej poległym w 1652 roku, a zatytułowanej Nagrobek mężnym żotnierzom na Batowskich polach zginionym $i z$ hetmanem M[arcinem] Kalinowskim w/ojewodq] cz[ernichowskim] ${ }^{68}$, spoczywanie żołnierza na pobojowisku pod

${ }^{64}$ Tukidydes, cd. cit., s. 142-143.

65 Por. A. Nowicka-Jcżowa, Sarmaci i śmnierć. O staropolskicj poezji żatobnej, Warszawa 1992, s. 185-186; Z. Kuchowicz, Czlouiek polskiego baroku, Łódź 1992, s. 191-192.

${ }^{66}$ Poeci żolnierzom, s. 173 i komentarz na s. 604. Efekt potçguje nicwątpliwic zastosowana tu prozopopcja. Por. Z. Morsztyn, Muza domou'a, opr. J. Dür-Durski, t. 1, Warszawa 1954, s. 235-236. Por. J. Rećko, W kreggi poezji nagrobkowej polskiggo baroku, Ziclona Góra 1994, s. 140-141.

67 Por. I. L. Vives, Commentarii in libros S. Augustini „De civitate Dei”..., w: Augustyn z Hippony, De civitate Dei libri XXII... cum erudito Ioannis Ludotici Vivis Valentini commentario, Antverpiac 1600, s. 331; Augustyn cytuje wiersz z Lukana (,...capit ommia tellus/Quae genuit: caelo tegitur, qui non habet umam”) w rozdz. 12, ks. I. Z tego samego rozdziału Starowolski zaczerpnął, nicco znickształcając oryginał, motto swych Monumenta Samatarum... (op. cit.), umicszczone na odwrocic karty tytułowej. Prawdopodobne, iz koncept Lukana przcjęty został właśnic za pośrednictwem Augustyna. Fabian Birkowski w Kazaniu na pogrzebie Jana Karola Chodkieu'icza wychwalał zmarłcgo hetmana miçdzy innymi za to, że: ,jako jeden z hetmanów rzymskich, tak siç z trupem nicprzyjaciclskim obchodził, [iż] po zwyciçstwic pod Kircholmem, ciała kapitanów pozbicrawszy, uczynił im pogrzcb zacny, z wiclką pompa; przy którym sam był. Patrzyła na to Ryga sama, miasto wiclkic; szło to w posłuch do cudzych narodów z wiclkim ich podziwicnicm" (cyt. za: Paniq̨tki z dziejór' dawnej Polski, wyd. J. K. Radecki, Poznań 1842, s. 36).

68 Wg Nicsicckicgo (op. cit., t. 5, Lipsk 1840, s. 13) "hetman serca swoim dodając polegt”. 
nagrobkiem „z darnia” uznał za tytuł do chwały i przeciwstawił splendorowi marmurowego grobowca. Postawa wierności cnocie i honorowi, uwznioślona przez poetę, niweczyć ma sromotę poniesionej klęski.

Nie z marmuru w mauzolu,

Nie w ceglanym grobie,

Ale w otwartym polu

Odpoczywasz sobie,

O mężny, o serdeczny,

$\mathrm{Z}$ wojskiem twym, hetmanie,

Pamiątki godny wiecznéj,

Poko Polski stanie. (...)

Droższa sława Polaku,

Niż żywot kochany.

Więc wiedząc, o co idzie,

Zwątpiwszy w zwycięstwie,

Byliście Leonidzie

Porównani w męstwie.

Przemogła wielkość cnotę,

Zbite polskie ufce

I na wieczną sromotę

$\mathrm{Na}$ tej legły kupce.

Aleć droga sromota

I czyn to waleczny,

Nie szacując żywota,

Los znieść szczęścia wsteczny.

Więc, duchy świątobliwe,

Spoczywajcie w Bogu,

Których ordy złośliwe

Zniosły na Batogu.

Waszej tej wiecznietrwałéj

Cnocie za zarobek

Ręce nasze sypały

Ten $\mathrm{z}$ darnia nagrobek.

(w. $1-8,19-40)^{69}$

W dwuwierszu Żolnierz pod Batohem, wyraźnie korespondującym z przywołanym utworem, Kochowski odwołał się wprost do toposu nieba okrywającego poległego:

69 W. Kochowski, Utwory poetyckie. Wybór, opr. M. Eustachiewicz, Wrocław 1991 (BN I 92), s. 39-41, por. w niniejszym tekścic przyp. 55. Zob. też J. Rećko, op. cit., s. 138-140, 146. 
Nie pod żadnym marmurem, lecz pod niebem w polu Spoczywam; tego sława życzy mi mauzolu ${ }^{70}$.

W tym kontekście należy tu jeszcze przywołać wspomnienie Jana III Sobieskiego o bracie Marku, haniebnie ściętym po bitwie pod Batohem, wyrażające żal z powodu braku pochówku brata:

...krwią swą Marek starosta krasnostawski, starszy brat mój skropił pola ukraińskie nieszczęsne, i od przezwiska samego batoskie; ale i kości jego carent sepultura ani przyniesione super hoc, bo i z swoim tam poległ puklerzem, a co największa i wielkiej consideratijej i politowania godna, że ścięty nie rozegrzany w bitwie, ale nazajutrz, jako mówią, w zimnej krwi, przykładem okrucieństwa nigdy niesłychanym, bo toż się stało i tegoż dnia z kilkąnastą tysięcy spółtowarzyszów tej tak okrutnej tragoedijej ${ }^{71}$.

Ze względu na parenetyczną funkcję kultu poległych warto prześledzić pokrótce ideę bohaterskiej śmierci oraz jej upamiętnienia ku nauce współczesnym i potomnym w myśli Stanisława Żółkiewskiego. Sumuje się w niej znacząca część poruszonych powyżej wątków, nie tylko ideowych, ale i historycznoliterackich.

Według tradycji rodzinnej, zapisanej przez Jana III Sobieskiego, Źłłkiewskiemu, jak sam mówił, jeszcze w młodości przepowiedziana została bohaterska śmierć na polu bitwy ${ }^{72}$. Hetman szczerze i głęboko przejęty ideałami tak chrześcijańskimi jak i antycznymi, przynajmniej od 1606 roku (pierwszy znany nam testament, tzw. „A”) wyrażał na piśmie pragnienie służenia ojczyźnie nie tylko za życia, ale i po chwalebnej śmierci. W związku z tym obmyślał wręcz szczegóły dotyczące swego pochówku ${ }^{73}$, a idę̨ śmierci godnej i chwalebnej zarazem do ostatnich chwil życia z uporem starał się urzeczywistnić. We wspomnianym testamencie następującymi słowy zwracal się do syna:

I pogani tak rozumieli, że śmierć dla Ojczyzny słodka: nuż jeszcze dla wiary świętej, jeślić się trafi okazyja czynienia przeciwko Turkom, Tatarom, mówię do ciebie słowa Psalmu 26: Viriliter age, confortetur cor tuum; takim umysłem położyć żywot

\footnotetext{
${ }^{70} \mathrm{Ibidem}, \mathrm{s} .294$, Epigramata polskie po naszemu fraszki.

${ }^{71}$ Ekscerpt $z$ manuskryptu wtasnej ręki najjaśniejszego Króla J. Mci śp. Jana Trzeciego, w: Pisma do wieku i spraw Jana Sobieskiego, zebr. i wyd. F. Kluczycki, t. 1, cz. 1, Kraków 1880 (Acta Historica Res Gestas Poloniae Illustrantitia ab anno 1507 usque ad annum 1795, vol. II), s. 9. Tekst wspomnicniowy powstał prawdopodobnic przed inicjatywą ufundowania pomnika bratu w kościcle oo. Dominikanów w Zółkwi (1684-1693/94). Inskrypcja pomnika stwicrdza, żc grobowicc zawiera kości Marka Sobicskiego — zob. J. Petrus, Kościoty i klasztory Żótkwi, (dalej: Kościoty), Kraków 1994 (Materiaty do dziejów sztuki sakralnej na ziemiach wschodnich dawnej Rzeczypospolitej, red. J. K. Ostrowski, cz. 1: Kościoly i klasztory rzymskokatolickie dawnego województwa ruskiego, t. 2), s. 102-104; por. K. Nicsiecki, op. cit., t. 8, s. 436). Warto tu jeszczc przypomnieć, że wśród obrazów, jakie znalazły się w fundowanym przez Teofilę z Daniłłowiczów Sobicską kościcle i klasztorzc Dominikanów, znalazł się też portret Marka Sobieskiego datowany na trzecią ćwicrćXVII wicku (obecnic w klasztorze oo. Dominikanów w Krakowie), opatrzony następującą subskrypcją w majuskule barokowcj: ,Illustrissimus Marcus a Sobieszyn Sobieski Capitaneus Crasnostaviensisfilius illustrissimae Fundatricis, anno aetatis suae 24 sub Batoho in Valachia pro bono Reipublicae victor gloriosus occubuit anno Domini 1652". Zob. J. T. Petrus, w: Odsiecz wiedeńska 1683. Wystawa jubileuszowa $w$ Zamku Królewskim na Wawelu $w$ trzechsetlecie bituy. Tto historyczne i materiaty źródłowe, t. 1 , Kraków 1990, s. 126-127; t. 2, il. 69; idem, Kościoly..., s. 110 i fig. 296-297.

${ }_{72}$ Zob. Ekscerpt..., op. cit., s. 7.

${ }^{73}$ Por. w niniejszym tekście przyp. 20.
} 
i u ludzi sławno, i u Pana Boga (co jest najwiętsza) odpłatno. (...) Co rzekł cny Aeneas synowi swemu, mówię i ja tobie: Disce puer ex me virtutem verumque laborem ${ }^{74}$.

W tym samym testamencie za wzór bohatera stawiał Żółkiewski Władysława Warneńczyka:

Sławniejszy żywot i chwalebniejsza śmierć Władysława króla, co u Warny zginął, niźli wielu innych, co na ich nagrobki patrzymy ${ }^{75}$.

W Pobudce do cnoty, którą Żółkiewski napisał w 1612 roku, by wydać dopiero w roku $1618^{76}$, o śmierci bohaterskiej i straceńczej, a także hańbie ucieczki przed wrogiem rozprawiają Spartanie („Lakonowie”) i sam Leonidas, w przededniu starcia z wojskami Kserksesa pod Termopilami.

Interesująca analogia zachodzi między utworem Żółkiewskiego a przywoływanym już ustępem Quincunxa... Orzechowskiego, w którym wspomina on bohaterów walk z Moskwą, Tatarami i Wołoszą. Orzechowski przypomniał w nim — jak pamiętamy — dwóch bohaterów sokalskich: Mikołaja Firleja i Fryderyka Herburta ${ }^{77}$, dawszy krótki opis ich zgonów, przy czym w przypadku Herburta podał też jego przedśmiertne wypowiedzi. Jednocześnie przywołał przykład Spartan spod Termopil, a słynne słowa Leonidasa: „Gińcie dzielni duchem, o Lacedemończycy, może ucztować dziś będziem u bogów podziemia”, porównał do tych, które przed ostatnim starciem „wołał krzykliwie” do swych towarzyszy Fryderyk Herburt:

Tu, o wierna drużyno, gardła dajmy, cześć panu swemu po sobie zostawmy; miejsca lepszego nie będzie ku temu na potym, by cnota zapłatę swą w Polszcze miała.

Następnie pyta Orzechowski:

I nie był-li by był ten Herbort z Fulsztyna z drużyną swą onego pogrzebnego u Polaków napisu godzien, który Leonidas ón zacny u Spartanów z Lacedemona mial? ${ }^{78}$,

po czym przytacza słynny dystych (uważany wówczas za dzieło Simonidesa) w łacińskiej wersji Cycerona z Rozmów Tuskulaniskich.

Te same motywy, łącznie z przypomnieniem postaci Herburta jako wzoru sarmackiego rycerza i nawiązaniem do jego przedśmiertnych wypowiedzi z przekazu Orzechowskiego, odnajdujemy w zakończeniu dziełka Źłłkiewskiego ${ }^{79}$. Zamyka je zasadniczo Nagrobek tych ludzi rycerskich i Drugi $z$ greckiego, będący tłumaczeniem-parafrazą dystychu pseudo-Simonidesowego:

${ }^{74}$ Zob. S. Żółkicwski, Pisma..., op. cit., s. 175, por. Wergiliusz, Eneida, ks. XII, w. 435-436.

${ }^{75}$ S. Żółkicwski, Pisma..., op. cit., s. 178.

${ }^{76}$ Zob. ibidem, s. 458-467, por. A. Biclowski, Wstęp, ibidem, s. LII-LIII oraz s. 458 (przyp.); por. omówicnic utworu w: J. Kuczyńska, Stanistaw Zótkieu'ski hetman i pisarz, Wrocław 1988, s. 5-18.

${ }_{77}$ Zob. S. Orzechowski, Quincunx..., ed. cit., s. 567-568.

${ }^{78}$ Ibidem, s. 568.

79 Żółkicwski kilkakroć zaznacza, żc hańbą okrywa ryccrza krycic siç za murami i oczckiwanic tam ataku wroga, co znamy z pieśni Sçpa Szarzyńskicgo. Główną część dzicłka kończy sentencja: „Nie chcemy więcej mówić. Miła czci, dla ciebie dziś radzi gardla damy”. Po czym następujc jeszcze odautorski komentarz: „Greckic to, ale i w naszym narodzic słowiańskim siła się znajdowało tak odważnych przykładów: pod Sokalcm tęż piosnk̨̧ śpicwając Fredrusz żywot swój skończył" (S. Żółkicwski, Pisma..., op. cit., s. 464-465, por. S. Orzcchowski, Quincunx..., loc. cit.). 
W powołaniu swym zawżdy przystojnieśmy żyli, A tu dla praw ojczystych zdrowia położyli ${ }^{80}$.

W Pobudce... w usta jednego z Lakończyków Żółkiewski włożył też słowa Horacego:

Szkoda wiele mówić. Słodka i uczciwa była zawżdy rzecz dla Ojczyzny życie położyć $\dot{c}^{81}$.

Wedle zalecenia hetmana z testamentu z roku 1606, wszelkie poświęcone mu po śmierci funebria dziać się miały

...nie dla chluby żadnej, lecz dla pamiątki i dla pobudki drugich do cnoty i nieszanowania się dla Ojczyzny ${ }^{82}$.

W kolejnym znanym nam testamencie z roku 1618 (tzw. „B”) czytamy:

A jeżeliby w Wołoszech albo gdzie za granicą śmierć Pan Bóg przysłał, tamże pogrześć grzeszne ciało moje, a na temże miejscu mogiłę wysoką usuć; nie dla ambicyjej jakiej tak mieć chcę, ale żeby grób był kopcem Rzeczypospolitej granic, żeby się potomny wiek wzbudzał do pomnożenia i rozszerzenia granic państw Rzeczypospolitej ${ }^{83}$.

Woli hetmana po części stało się zadość. Ciało jego spoczęło ostatecznie w Żółkwi, w miejscu zaś, gdzie poległ, na polach pod Mohylewem, usypano kopiec, na którym stanął pomnik z pamiątkowym napisem $^{84}$. Treść jego podał dwukrotnie Starowolski w Monumnenta Sarmatanım ${ }^{85}$. Napis skomponowany został jako prozopopeja: jakby hetman osobiście zwracał się do „przychodnia”, między innymi słowami Horacego i Wergiliusza: „Ktokolwiek tu przybywasz, ucz się ode mnie, jak słodko i zaszczytnie jest umrzeć za Ojczyznę” („Quisquis ades, quam dulce et decorum sit pro Patria mori ex me disce") ${ }^{86}$. Zdanie to jest kompilacją słynnej frazy Horacjańskiej: Duke et decontm est pro

${ }^{80}$ S. Żólkicwski, Pisma..., loc. cit. Po nagrobkach następuje jeszcze dołączony do dzicłka tckst Bogurodzicy.

81 Ibidem, s. 463, por. s. 460 i 464; Q. Horatius Flaccus, Carmina III 2, 13.

${ }^{82}$ S. Źółkicwski, Testament z r. 1606, op. cit., s. 179, gdzic po cytowanych słowach czytamy: „Nagrobck też bez chlubnych słów; radzić się pana Symonidesa”, tj. Szymona Szymonowica; por. w ninicjszym tekścic przyp. 20.

${ }^{83}$ S. Żółkiewski, Pisma..., s. 290, zob. też ostatni list do żony pisany w wigilic̨ śmierci, ibidem, s. 381-382. Por. mowç Źłłkiewskicgo z 1618 roku: Dziękowanie za wielkq buławę, w: cd. cit., s. 397-398: „...z miłościwych rąk Pańskich [tj. królewskich - M. J.] to wojenne żclazo [tj. buławç - M. J.] w ręce moje biorę, żem gotów, jeśliby tak mi propitia przyniosły fata, jeżeli non virtute et ferro, przynajmnicj cadavere przystępu nicprzyjacielowi do Ojczyzny bronić"; por. w ninicjszym tckścic przyp. 52.

${ }_{84}$ Pomnik ten istnial jeszcze w roku 1843. Zob. M. Baliński, Zgon Źótkiewskiego w cecorskiej urypraurie i ponmik jego w Besarabii, w: idcm, Studia historyczne, Wilno 1856, s. 227-321. O śmicrci hetmana i wystawieniu pomnika zob. też: R. Majewski, Cecora - rok 1620, Warszawa 1970, s. 216-217; Ekscerpt..., op. cit., s. 4; M. Costin, Latopis Ziemi Moldawskiej i inne utwory historyczne, tł., wst. i koment. I. Czamańska, Poznań 1998, s. 135.

${ }^{85}$ Zob. S. Starowolski, Monumenta Sarmatarum, op. cit., s. 476-477, gdzie przed tekstem inskrypcji czytamy: „In sublimi colle sphaerice aggesto, Zolkievianae memoriae pro Patria et fide occumbenti in Valachia, trans Tyram, colossus haec habct: (...)"; por. ibidem, s. 755-756 oraz A. Biclowski, Wstęp, w: S. Zólkiewski, Pisma, op. cit., s. LVIII-LIX. Napis skicrowany jest do „przychodnia” tak chrzcścijańskicgo, jak i mahometańskicgo wyznania z prośbą o uszanowanic micjsca (oczywiścic napis łaciński przez wyznawców Proroka, zwanych w nim zresztą tradycyjnic „poganami”, nic mógł być czytany).

${ }^{86}$ Zob. S. Starowolski, op. cit.; A. Biclowski, op. cit. Jak często w praktyce epigraficznej, tak zapcwnc i w przypadku 
patria mori (cytowanej powyżej w polskiej wersji z hetmańskiej Pobudki...) oraz Wergiliańskich słów Eneasza skierowanych do Askaniusza, które hetman w testamencie z roku 1606 adresował do syna Jana — również powyżej cytowanych ${ }^{87}$.

Wybór na pomnik cecorski frazy z Horacego podyktowany był nie tylko jej stosownością. Szczególne upodobanie Żółkiewskiego w poezji rzymskiego arcypoety, przejawiające się częstym cytowaniem jego sentencji, znane było współczesnym ${ }^{88}$. Sądzić można, że ten właśnie fragment o zaszczycie śmierci za Ojczyznę, który hetman umieścił w swej Pobudce..., często był przez niego przywoływany, a być może także wskazany w którymś z nieznanych dziś testamentów, jako przeznaczony na pomnik grobowy ${ }^{89}$. Według relacji samego Jana III Sobieskiego owa fraza z Horacego była jednym z pierwszych zdań łacińskich, którego uczył się, czytając „z nagrobku pradziada”. Ona więc miałaby pierwotnie widnieć na nagrobku hetmańskim w kolegiacie zółkiewskiej, względnie też na sarkofagu hetmana, zanim na obydwu tych obiektach, za sprawą króla, umieszczony został słynny wiersz z Eneidy (IV, 625): „Niechaj powstanie mściciel z naszych kości” (Exoriare aliquis nostris ex ossibus ultor). W cytowanych już wspomnieniach o przodkach Jan III Sobieski zapisał:

Rodzice nasi procreati fortes ex fortibus (bo i matka nasza nie białogłowskiego, ale męskiego była serca, największe za nic sobie mając niebezpieczeństwa) wprawowali nas z młodu, abyśmy nie byli degeneres od przodków swych, wystawując nam na oczy jeszcze w dziecinnych będącym wieku wielką sławę ich, ochotę i odwagę na zaszczyt Kościoła i Ojczyzny, kazawszy nas zaraz z abiecadłem tego wiersza uczyć z nagrobku pradziada naszego $O$ quam dulce et decorum pro patria mori ${ }^{90}$.

Niech to wspomnienie zwycięzcy spod Chocimia i Wiednia stanie za sumę powyższego przeglądu, jako świadectwo wagi kultu poległych w dawnej Polsce, kultu, który obliczony na społeczną i rodową parenezę, umiał istotnie przekładać się na czyny.

\footnotetext{
tego cytatu mamy do czynienia ze zwtóceniem uwagi na pewną wiçkszą całość myślową, wraz z intencją osadzenia jej we współczesnym i właściwym cytującemu kontekście. Frazę Horacjańską wykorzystuje późniejsze, nicdatowane epitafium Piotra Gnojeńskiego w Chmielniku, zastrzclonego przez kozaków (zob. S. Starowolski, op. cit., s. 316-317; K. Niesiecki, op. cit., t. 4, Lipsk 1839, s. 161).

${ }_{88}^{87}$ Por. w niniejszym tekście przyp. 74 i 81.

${ }^{88}$ Zob. np. K. Niesiecki, op. cit., t. 10, Lipsk 1845, s. 185.

${ }^{89}$ Por. S. Źłłkiewski, Testament z roku 1618: „Zwykłem każdego nicmal roku odnawiać testament, uczyniłem to i roku przeszłego (...)" w: idem, Pisma..., op. cit., s. 290); por. jednak w ninicjszym tckście przyp. 20 i 82.

${ }^{90}$ Excerpt..., op. cit., s. 8. Zapewne owe lekcje przy nagrobku pradziada odbywały się między rokicm 1638 (objęcie przez Sobieskich Zółkwi) a początkicm roku 1640 (wyjazd Marka i Jana Sobieskich na naukę do Krakowa, gdzie zresztą napotykamy w programie edukacyjnym lekturę Horacego i Eneidy, a także dowody żywej tradycji związanej ze śmicrcią Zółkiewskicgo (por. R. Aftanazy, Dzieje rezydencji na dawnych kresach Rzeczypospolitej, t. 7: Województwo ruskie, ziemia halicka i lwowska, Wrocław 1995, s. 606; H. Barycz, Rzecz o studiach w Krakowie dwóch generacji Sobieskich, Kraków-Wrocław 1984, s. 24, 36, 45-46).

W świctle cytowanych tu pism samego Źółkiewskicgo i rclacji pochodzącej od Jana III Sobicskicgo napisy związane z pochówkiem hetmana w Żółkwi wymagają osobnych uwag. Ich dzieje nic znalazły bowiem zadowalającego objaśnienia we wspominancj wczcśniej (zob. przyp. 71) ostatnicj monografii zabytków sakralnych tego miasta autorstwa Jerzego T. Petrusa (Kościoly i klasztory Źólkwi, Kraków 1994). Wraz z fragmentami dekoracji sarkofagu hetmańskiego wykonanego zapewne krótko po 1620 roku (Muzeum Narodowe w Warszawic — Oddział w Wilanowie) zachował się ułożony z pojedynczo wykonanych cynowych liter napis-cytat z Eneidy (ks. IV, w. 625) w nicco
} 
zmienionym brzmieniu: „Exoriare aliquis de nostris ossibus ultor”. Ze wzglc̨du na barokową stylistykę liter sądzić należy, że pochodzi on dopiero z czasów restauracji sarkofagu zrealizowanej na polecenic Jana III w latach 1689-1690. Być może zastapił on wtedy napis horacjański przytoczony przez samego Jana III (o ile miał on na uwadze sarkofag) w cytowanym wspomnieniu. Przed rokiem 1809 fragmenty zdewastowanego sarkofagu znajdowały sic̨ już u Czartoryskich w Puławach. Była wśród nich tablica z herbem Lubicz, prawdopodobnie z frontowcj, dolncj ściany sarkofagu. Zapewne sarkofag opatrzony był także inskrypcją identyfikacyjną o charakterze cpitafium i ta mogła zawierać frazę z Horacego. (por. J. T. Pctrus, w: Odsiecz wiederiska 1683, op. cit., t. 1, s. 95-97; t. 2, il. 20-23 [dalcj: Odsiecz]; Kościoly, fig. 189-190). Liternictwo napisu „Exoriare aliquis...” łączoncgo z sarkofagiem, jak i polskiego napisu dedykującego sarkofag hetmanowi, porównać można choćby z grafią noty o śmicrci Teofili Sobicskicj (zm. 1661) z repliki jej portretu z kościoła Dominikanów w Źółkwi, datowanej na koniec XVII wicku (obecnic w krakowskim klasztorze Dominikanów). Znamienne, że oryginał tego portretu (ukazującego modelkę w stroju żałobnym, zapewne po śmierci syna Marka pod Batohem, a przechowywanego obecnic w tym samym micjscu co kopia), opatrzony jest napisem, wykonanym po śmicrci sportretowanej, w regularnej kapitale barokowej, tak zreszta jak pierwsza część napisu na replice, identyfikująca osobę (zob. Odsiecz, t. 1, s. 126; t. 2, il. 68; Kościoly, s. 110 i fig. 294-295). Podobnie dodatkowych uwag wymagają dzicje napisu „Exoriaire aliquis...”, widnicjąccgo na nagrobku hetmańskim zapewne od czasów Jana III. J. T. Petrus stwierdził jedynic, że napis ten, jak i właściwa inskrypcja epitafijna, pochodzą z czasów odnowienia nagrobka przez Parysa Filippicgo w latach 1861-1868 i mają być wicrnym powtórzeniem napisów widocznych jeszcze w 1843 roku, a wg tradycji wykonanych z inicjatywy króla Jana III (zob. Kościoły, s. 28 i 29, gdzie też tekst obecnego napisu). W picrwszym wydaniu pracy ks. Sadoka Barącza o zabytkach Żółkwi (Pamiq̨tki miasta Źólkwi, Lwów 1852), nicdostatecznic wyzyskanym przez J. Pctrusa, po opisic posągów hetmana i jego syna w ich nagrobku czytamy: „U spodu był niegdyś na czarnym marmurze mosiçżnymi grubo złoconymi literami wypukły napis z Wirgiliusza: «Exoriare aliquis nostris ex ossibus ulton” (s. 98). W drugim natomiast wydaniu pracy Barącza (Lwów 1877), w odmicnnic już zredagowanym tekście, w odniesieniu do obydwu pomników w prezbiterium kościoła (a nic, jak sugeruje Petrus - choć zapcwne słusznic — do samych napisów) czytamy: „Zdaje siç, żc dawnicj inne były [pomniki - M. J.], a teraźnicjsze wznicsione zostały przez króla Sobicskicgo, na których w roku 1843 oglądałem ślady liter wypukłych; na pierwszym z Wirgiliusza: «Exoriare aliquis...»” (s. 204). Zapewne więc istotnic, na co zdają się wskazywać również przedstawione powyżcj wnioski odnośnie zachowanych napisów z sarkofagu, napis „Exoriare aliquis...” w postaci metalowych, mocowanych w marmurzc wypukłych liter umicszczony został na pomniku z polecenia Jana III. Przckaz Starowolskiego sprzed 1655 roku (na podstawic którcgo w latach sześćdziesiątych XIX wieku odtworzono zniszczone przez Austriaków inskrypcje, poświçcone hetmanowi i jego synowi) cytatu $z$ Wergiliusza nie zawiera, podobnie zresztą jak nic zawicra sugerowancj przez relację Sobicskicgo frazy Horacjańskiej - por. S. Barącz, wyd. 1877, s. 204 (u dołu, zdanie wprowadzające teksty inskrypcji) i s. 205 (inskrypcje), por. S. Starowolski, op. cit., s. 477-478. Nalcży przy tym podkreślić, iż dodatkowcgo wyjaśnicnia wymagałyby jeszcze, sygnalizowane przez Petrusa, opuszczenia dokonane w odtwarzanym przez Filippicgo napisic ze względów politycznych i ich ewentualne uzupełnienia z lat dwudziestych XX wieku. Ponieważ przckaz Barącza z 1877 roku zgadza się w pełni z wersją Starowolskicgo, nalcży sądzić, że „opuszczenie” to dotyczyć by mogłojedynic napisu „Exoriare aliquis...”, a ten — jak przypomnieliśmy wyżej za Petrusem - został przez Filippicgo odtworzony. Widnieje on także na stalorycie z drugiej połowy XIX wieku, przedstawiającym nagrobek, i na drzeworycic W. Bojarskiego z tego samego czasu (zob. Kościoly, fig. 140 i 141), choć te mogą też nawiązywać do stanu przcd zniszczeniem dawnych napisów. Znamienne, że motyw pomsty i określenie „ultor” pojawiają sic̨ na dwóch innych nagrobkach w Źółkwi, fundowanych przez Jana III: Stanisława Daniłowicza (zm. 1637 — o jego śmicrci patrz Ekscerpt ..., op. cit., s. 6; K. Niesiecki, op. cit., t. 3, Lipsk 1839, s. 303), dzicle Andrzcja Schlütera z lat 1692-1693, w kolcgiacic zółkicwskicj (zob. Kościoly, s. 30-opis, s. 32 - tekst inskrypcji) oraz w wykończonym w tym samym czasic i zapewne przcz tego samego artystę nagrobku Marka Sobieskiego, do kościoła Dominikanów (zob. Kościoly, s. 102 — opis, s. 103-104 — tekst inskrypcji). Należy jednak zwrócić uwagę, że inskrypcję z pomnika Daniłłowicza z frazą "aviti sanguinis ultor” znajdujemy już u Starowolskiego, a więc pochodzi ona sprzed 1655 roku (Starowolski, op. cit., s. 478-479, zob. tcż s. 304-305). Zauważmy na koniec, że napis „Exoriare aliquis...” może być rozpatrywany jako clement propagandy politycznej Jana III. Któż bowiem, jak nic On, stał sį̨ owym „mściciclem”? 